\title{
Is Selective Distribution Possible on the Internet? On Restrictions of Online Search Advertising and Online Sales in the Guess Case
}

\author{
by
}

Bartosz Targański*

\section{CONTENTS}

I. Introduction

II. Guess' e-commerce strategy

III. Restrictions of online search advertising

IV. Online sales restrictions

V. Comments

VI. Value-Added Service Pricing Model

\begin{abstract}
This comment discusses the case AT.4028 of 17 December 2018, where the European Commission imposed a fine of 39.8 million Euro on clothing company Guess for several restrictive provisions in agreements with its distributors in the EEA, including restrictions of online search advertising and online sales. The case demonstrates that e-commerce leads to disintermediation within the supply chain, which in turn leads to tensions between the manufacturer of branded products and authorized distributors operating in a selective distribution system. The case does not provide, however, much practical guidance on how to align online and offline channels into one distribution system supporting a prestigious image of branded products. Therefore, an example of a distribution system integrating online and offline sales from the practice of the Australian Competition and Consumer Commission is presented.
\end{abstract}

* Assistant professor at the Warsaw School of Economics (SGH), legal advisor and doctor of economics specializing in competition protection in the digital economy; email: btarga@ sgh.waw.pl; ORCID: 0000-0002-5338-3936

Article received: 21 May 2020, accepted: 15 June 2020. 


\section{Résumé}

Ce commentaire examine l'affaire AT.4028 du 17 décembre 2018, dans laquelle la Commission européenne a imposé une amende de 39,8 millions d'euros à la société de vêtements Guess pour plusieurs mesures restrictives contenues dans des accords avec ses distributeurs en EEE, y compris des restrictions de la publicité sur les moteurs de recherche en ligne et des ventes en ligne. Laffaire démontre que le commerce électronique engendre une désintermédiation au sein de la chaîne d'approvisionnement, qui à son tour entraîne des tensions entre le fabricant de produits de marque et les distributeurs autorisés opérant dans un système de distribution sélective. Laffaire ne fournit pas beaucoup d'indications pratiques sur la manière d'aligner les canaux en ligne et hors ligne dans un système de distribution unique soutenant une image prestigieuse des produits de marque. C'est pour cette raison qu'un exemple de système de distribution intégrant les ventes en ligne et hors ligne, emprunté à la pratique de l'Australian Competition and Consumer Commission, est exposé.

Key words: brand products; e-commerce; online sales; online search advertising; vertical restraints.

JEL: K21, L410, L810

\section{Introduction}

In the Decision of 17 December 2018 (hereinafter, Decision or Guess Decision $)^{1}$ the European Commission fined the clothing company Guess $€ 39.8$ million for several restrictive provisions in agreements with its distributors in the EEA, including restrictions of online search advertising and online sales in the period from 1 January 2014 to 31 October 2017. The case is interesting as it reveals the e-commerce strategy of a global company concerning branded products. In particular, it demonstrates that e-commerce leads to disintermediation within the supply chain, which in turn leads to tensions between the manufacturer of branded products and authorized distributors operating in a selective distribution system. The Decision does not provide, however, much practical guidance for companies on how to align online and offline channels into one distribution system supporting a prestigious image of branded products. Therefore, an example of a distribution system integrating online and offline sales will be presented from the practice of the Australian Competition and Consumer Commission.

\footnotetext{
${ }^{1}$ Commission decision of 17 December 2018, Case AT.40428 Guess.
} 


\section{Guess' e-commerce strategy}

The products concerned by this Decision are the apparel and accessories lines marketed in Europe at the wholesale and retail level under numerous trademarks, and, in particular, apparel, denim, swimwear, underwear, footwear, footwear kids, jewellery and accessories, each for men, women and kids ${ }^{2}$. Guess products are marketed under trademarks including 'GUESS', 'MARCIANO', 'GUESS Kids', 'Baby GUESS', 'YES'. ${ }^{3}$ At retail level, Guess products are distributed in bricks-and-mortar stores operated by (a) Guess and its affiliates, (b) independent third parties in mono-brand stores only with Guess products, (c) third party-owned multi-brand retailers across the EEA. ${ }^{4}$ Guess also sells its products online directly through its own online store (www.guess.eu) and on online marketplaces. The major element of Guess' commercial strategy was the development of an e-commerce strategy. According to Guess' internal document: 'e-commerce is the most important channel for a Company, which gives first brand positioning and integrity perception to customers. It's the fastest growing channel. It has to be given priority in showing/selling products, launching promotions and investing in the brand presentation'. ${ }^{5}$

In connection with this, Guess has been developing its website with an online store since 2009 and mobile channels with the intention to "create a winning ecommerce and mobile platform to overperform the market' ${ }^{6}$ An element of that strategy was to direct Internet traffic from distributors selling Guess' products to Guess' website 'to avoid cannibalisation of the official Guess website'. ${ }^{7}$

\section{Restrictions of online search advertising}

To implement its e-commerce strategy, Guess was controlling the expansion of online sales by its authorised retailers, both mono-brand and multi-brand retailers, by banning the use of the Guess brand names and trademarks in Google AdWords in the EEA. ${ }^{8}$ According to Guess' internal documents: 'Our

2 Ibidem, para. 11.

3 Ibidem, para. 2.

${ }^{4}$ Ibidem, para. 21.

5 Ibidem, para. 35.

6 Ibidem, para. 35.

${ }^{7}$ Ibidem, para. 36.

8 Ibidem, paras. 40 and 44. 
strategy and goal is to grow our B2C channel and Google search is a very important marketing channel that gives our B2C site an advantage when our ads appear first or are the only ads using the Guess Trademark'. ${ }^{9}$

Google AdWords is the largest and most widely used online search advertising service that was generating between $20 \%$ to $40 \%$ of the visits to Guess official online shop during the infringement period. ${ }^{10}$ The ban to use Guess' brand names was not formally included in the distribution agreements but was systematically applied in response to authorised retailer requests for approval. ${ }^{11}$ The ban to use Guess brand names and trademarks as keywords in Google AdWords restricted the 'findability' of authorised online retailers within Guess' selective distribution system. ${ }^{12}$

The Commission found that the purpose of the ban was to maximise traffic to Guess's official website. Restrictions on distributors advertising activities are not a new phenomenon in competition law, as they were assessed already before the Internet era. In Hasselblad, ${ }^{13}$ the Court of Justice found that a contract clause that permits the supplier to scrutinize the wording of dealers' advertisements regarding selling prices, and to prohibit such advertisements, constitutes an infringement under Article 101(1) TFEU and it cannot be justified as a tool to ensure a 'common advertising programme of a high standard'. National competition authorities have also dealt with various forms of restrictions on distributors' advertising. ${ }^{14}$ The use of trademarks as keywords for search engine positioning has also already been reviewed in Google France, ${ }^{15}$ where the Court of Justice found that the trademark owner is entitled to prohibit advertising, based on a keyword identical with that trademark, if that advertisement does not enable an average internet user, or enables only with difficulty, to ascertain whether the goods or services referred

9 Ibidem, para. 49.

10 Google AdWords allows sellers, by reserving or bidding on one or more keywords, to obtain the placing of an advertising link to their website whenever an internet user enters one or more of those keywords as a request in the Google search engine. The advertising links typically appear on Google's general search results pages next to the so-called generic/natural search results (para. 51).

11 Ibidem, para. 46.

12 Ibidem, para. 52.

13 ECJ judgment of 21 February 1984, Case 86/82 Hasselblad v Commission, ECLI:EU:C:1984:65, para. 49.

14 E.g. Decision of the Office of Fair Trading, Roma-branded mobility scooters: prohibitions on online sales and online price advertising, CE/9578-12, 5 August 2013; Decision of the Office of Fair Trading, Mobility scooters supplied by Pride Mobility Products Limited: prohibition on online advertising of prices below Pride's RRP, CE/9578-12, 27 March 2014.

15 CJEU judgment of 23 March 2010, Joined Cases C-236/08 to C-238/08 Google France, ECLI:EU:C:2010:159, para. 99. 
to therein originate from the trademark owner or an undertaking economically connected to it or, on the contrary, originate from a third party.

In the Guess Decision, the Commission found that there is no risk of confusion, as Guess' products are offered by authorized distributors in the selective distribution system, not by third parties. ${ }^{16}$ The Commission considered the exclusivity to use Guess brand names in AdWords provided Guess with a considerable competitive advantage over its retailers with whom it competed online and restricted intra-brand competition. ${ }^{17}$ Therefore, online search advertising restrictions cannot be said to serve to protect the brand image. ${ }^{18}$

Another goal of restrictions concerning the use of Guess' brand names and trademarks was the reduction of advertising costs of Guess. According to Guess internal documents: 'Letting our B2B customers bid on Google terms drives up our advertising costs and puts our B2C site at a distinct disadvantage.'19

In AdWords, the position of an advertisement in Google ranking depends on the maximum amount that an advertiser is willing to pay for a click made by Internet users and on relevance and usefulness of the advertisement to users (based on Google's algorithm). ${ }^{20}$ In effect, competition between numerous advertisers for specific keywords increases the cost per click and the overall advertisement cost. ${ }^{21}$ The Commission referred to Interflora $v$ Marks \& Spencer case, where the Court of Justice argued that the mere fact of using by a third party of a keyword identical with a trademark is not sufficient basis in every case for concluding that the trade mark's advertising function is adversely affected. Although the trademark is an essential element in the system of undistorted competition, its purpose is not, however, to protect its owner against practices inherent in competition. The goal of Internet advertising using keywords identical with trademarks is merely to offer internet users alternatives to the goods or services offered by trademarks owner. ${ }^{22}$ The use by a third party of a keyword identical with a trademark obliges the trademark owner to intensify its advertising efforts. ${ }^{23}$

Finally, the Commission concluded that the reduction of advertising costs does not constitute a legitimate goal in the context of selective distribution. ${ }^{24}$ The restriction was classified as a 'by object' infringement within the meaning

16 Guess Decision, para. 117.

17 Ibidem, para. 121.

18 Ibidem, paras. 118-119.

19 Ibidem, para. 49.

20 Ibidem, para. 42.

21 Ibidem, para. 44.

22 CJEU judgment of 22 September 2011, Case C-323/09, Interflora v Marks \& Spencer, ECLI:EU:C:2011:604, paras. 57-58.

23 Guess Decision, para. 122.

24 Ibidem, para. 123. 
of Article 101(1) TFEU, as it was aimed at reducing the ability of authorised retailers to advertise and ultimately to sell products to customers and to limit intra-brand competition. ${ }^{25}$

\section{Online sales restrictions}

Another element of Guess' e-commerce strategy was the limitation of the number of independent distributors with the right to sell Guess products online. Retailers (both purely online and hybrid retailers) were required to obtain explicit authorisation from Guess for online sales. According to Guess internal document: '(...) all sales made through the Internet must be authorized by the E-Commerce department. ${ }^{26}$

The decision to grant authorisation was not based on a set of quality criteria. Guess neither formally adopted a list of quality criteria nor communicated conditions for online sales entitling distributors to sell on the Internet. ${ }^{27}$ Guess had full discretion whether to grant permission to online sales or not. ${ }^{28}$ The Commission also found that the entire wording and spirit of the retail agreements concerned offline activities, and suggested that mono-brand retailers were supposed to carry out offline sales activities only. ${ }^{29}$ For example, all evaluation criteria used for multi-brand retailers wishing to be admitted to the Guess selective distribution network referred to physical outlets only, that is, type, number of windows, turnover, area, number of employees, external appearance (including street facade, windows), internal appearance (including flooring, walls ceiling, fixtures, advertising, brand identification), overall impression, and information on the brands sold per product category. Wholesalers were also required to attach photos of the retail store, internally and externally, and neighbouring stores. ${ }^{30}$

The assessment of online sales restriction by the Commission was rather straightforward. The Commission referred to the Guidelines on Vertical Restraints $^{31}$ (hereinafter, Vertical Guidelines) stating that '(...) In principle, every distributor must be allowed to use the internet to sell products ${ }^{32}$ and

25 Ibidem, paras. 124-126.

26 Ibidem, para. 61.

27 Ibidem, para. 62.

28 Ibidem, para. 53.

${ }^{29}$ Ibidem, para. 56.

30 Ibidem, para. 59.

31 Commission notice - Guidelines on Vertical Restraints, OJ C 130, 19.05.2010, p. 1.

32 Vertical Guidelines, para. 52. 
settled case law (Pierre Fabre and Coty). In Pierre Fabre, the Court of Justice held that in the context of a selective distribution system, a contractual clause, resulting in a ban on the use of the internet for those sales, amounts to a restriction by object within the meaning of Article 101(1) TFEU. ${ }^{33}$ In Coty, the Court of Justice held that Article 101(1) TFEU allows for a restrictive clause in a selective distribution system, on condition that the clause has the objective of preserving the luxury image of those goods, that it is laid down uniformly and not applied in a discriminatory fashion, and that it is proportionate in the light of the objective pursued. ${ }^{34}$

Against this background, the Commission found that the written authorisation required by Guess was not linked to any specified quality criteria. It was part of the e-commerce strategy to promote Guess' online shop and had, as its main object, to restrict sales on authorised retailers' websites. Therefore, such authorisation requirement constitutes a restriction by object within the meaning of Article 101(1) TFEU. ${ }^{35}$

The Commission concluded also that the online search advertising restrictions and the online sales restrictions had the object of restricting active or passive sales to end users by members of the selective distribution system operating at the retail level of trade. Thus, in the meaning of Article 4(c) of VBER, ${ }^{36}$ those restrictions cannot benefit from the block exemption. ${ }^{37}$ The Commission found also no indications that the restrictions contributed to improving the production or distribution of Guess' products, or to promoting technical or economic progress while allowing consumers a fair share of the potential benefits resulting from Guess' restrictive practices. In addition, the Commission found no indications that the conduct was indispensable, for example to address free-riding, or to protect Guess' brand image. Thus, Guess' did not benefit from the individual exemption under Article 101(3) TFEU. ${ }^{38}$

33 The unlawful requirement in Pierre Fabre was a clause requiring sales of cosmetics and personal care products to be made in a physical space where a qualified pharmacist must be present. See CJEU judgment of 13 October 2011, Case C-439/09 Pierre Fabre Dermo-Cosmétique, ECLI:EU:C:2011:649, para. 47.

34 CJEU judgment of 6 December 2017, Case C-230/16 Coty Germany, ECLI:EU:C:2017:941, para. 58.

35 Guess Decision, para. 131.

36 Commission Regulation (EU) No 330/2010 of 20 April 2010 on the application of Article 101(3) of the Treaty on the Functioning of the European Union to categories of vertical agreements and concerted practices, OJ L 102, 23.4.2010, p. 1-7.

37 Guess Decision, paras. 157-158.

38 Ibidem, paras. 163-164. 


\section{Comments}

The investigation in the Guess case started as a follow-up to the e-commerce sector inquiry ${ }^{39}$ and confirms the Commission's consistency in promoting digital competition in recent years. The added value of this case goes, however, beyond competition law and concerns management theory in the digital economy. The Guess e-commerce strategy reflects the ongoing disintermediation process, which consists of the removal of intermediaries from a supply chain. It should be stressed that the major factor of Guess' distribution strategy in Europe concerning brick-and-mortar shops was vertical integration, which was reflected in growing retail sales made directly by Guess. As pointed out by the Commission: 'Following a global companydriven strategy implemented since (at least) 2008, a material and growing percentage of Guess Europe's overall retail sales in the EEA were made by the company directly. 40

The disintermediation process, in connection with Guess' attempts to control online sales of authorized distributors, does not send an optimistic signal for the future of selective distribution as a concept. In the pre-Internet era, the division between brand owners and distributors was rather strict and transparent. A brand owner had to, as a rule, involve numerous entities to develop a relatively dense network of outlets, who sell the products and promote brand awareness in line with the brand owner's concept. In the Internet era, from a technical and organisational point of view, the involvement of distributors is not crucial anymore, as brand owners can sell and communicate independently with final customers. As the communication can be carried out independently, the division of roles in the supply chain between the brand owner and distributors is blurred. The brand owner is also increasingly becoming a distributor, that is, competes with traditional distributors. Moreover, traditional distributors may also want to use the opportunities of the Internet to reach out to more customers by applying a more aggressive pricing or advertising policy. In effect, competition within the selective distribution system gets more dynamic, which, in turn, may jeopardise the consistency of brand presentation.

Against this background, doubts arise as to the attractiveness of a selective distribution system for an owner of branded products in Internet-dominated commerce. The Decision brings two hints in this respect. The first hint is

39 Report from the Commission to the Council and the European Parliament - Final report on the E-commerce Sector Inquiry $\{\operatorname{SWD}(2017) 154$ final $\}$. Retrieved from: http://ec.europa. eu/competition/antitrust/sector_inquiries_e_commerce.html (7.03.2020).

${ }^{40}$ Ibidem, para. 37. 
that strict control of distributors' online sales violates EU competition law. This hint is quite obvious in light of the Commission's settled case law. The second hint is that to achieve compliance with competition law, owners of branded products need to apply objective quality criteria in a uniform and not discriminatory manner. Those hints are very general and do not provide practical guidance. Thus, the key question on how to reconcile online and offline activities of the manufacturer and distributor remains open after the Guess Decision.

\section{Value-Added Service Pricing Model}

Against the background of the Guess Decision, there is an example of a distribution system of a vertically integrated supplier of branded products that effectively aligned offline and online channels. Namely, in 2014 the Australian Competition and Consumer Commission (hereinafter, ACCC) approved the distribution system of strategic board games offered by Games Workshop Qz Pty Limited (hereinafter, GWOP) in Australia. ${ }^{41}$ The key element of the system was a value-added service pricing model (hereinafter, the VASP Model) whereby a distributor was 'scored' against certain value-added services offered to final customers. The higher the score, the greater the discount at which a distributor can purchase products. The criteria related to additional services were adapted to the specifics of both traditional outlets and online shops so that distributors could achieve maximum wholesale price discounts in both channels. GWOP demonstrated public benefits resulting from the VASP Model. In particular, it pointed out that the VASP Model provides an incentive for distributors to develop and activate the gaming community for the benefit of individual players. ${ }^{42}$

The ACCC admitted that this distribution model may result in a reduction of intra-brand price competition (or competition between retailers to supply GWOP products to consumers) and higher average retail prices for GWOP products, to the detriment of some consumers, as online-only retailers will be unable to supply GWOP products. Higher average retail prices may also result if the notified conduct (and in particular, the VASP) increases the wholesale price of GWOP products for retailers who offer a low level of retail

41 Statement of Reasons in respect of a notification lodged by Games Workshop Oz Pty Limited, Date: 19 November 2014, Notification no. N97404. Retrieved from: https://www.accc. gov.au/system/files/public-registers/documents/D14\%2B158590.pdf (7.03.2020).

42 Games Workshop Oz Pty Limited - Notification - N97404. Retrieved from: https://www. accc.gov.au/system/files/public-registers/documents/D14\%2B59305.pdf (7.03.2020). 
services, which may, in turn, lead to higher retail prices. However, the ACCC acknowledged that some customers are likely to value pre- and post- sales retail services so as to enhance their overall gaming experience. Also, the introduction of the VASP model is designed to reduce the risk that retailers with a low level of retail services free ride on the investment made by retailers with a high level of retail services. The ACCC acknowledged that without the GWOP, the incentive to provide high level retail services valued by customers would be undermined. ${ }^{43}$

In my view, the above distribution model would be very likely to meet the EU competition law requirement expressed in Coty, namely, a specific contractual clause within a selective distribution agreement is lawful under Article 101(1) TFEU provided that it had a legitimate objective, was laid down uniformly for all potential resellers, applied in a non-discriminatory fashion, and did not go beyond what was necessary. ${ }^{44}$ In addition, according to the Vertical Guidelines, a supplier operating a selective distribution system may legitimately require quality standards for the use of websites that resell its goods, just as the supplier may require quality standards for a brick-and-mortar shop, or selling by catalogue, or for advertising and promotion in general. ${ }^{45}$ In contrast to this, Guess' e-commerce strategy, was not linked to any specific quality criteria ${ }^{46}$, and Guess did not demonstrate that it was indispensable to address free-riding or to protect the brand image. ${ }^{47}$

In this regard, the Guess Decision brings practical implications for the compliance policy of branded product owners. As a starting point, they need to review the wording of their quality criteria in existing distribution documents (evaluation template agreements, instructions, and manuals for retailers), to make sure that they do not discriminate online channel, and to review their enforcement in practice. They should also develop a formal document with a list of quality criteria for online sales and communicate it in a transparent manner.

\footnotetext{
43 Statement of Reasons..., paras. 4.16-4.17.

44 C-230/16 Coty Germany, paras. 36 and 40.

45 Vertical Guidelines, para. 54.

46 Guess Decision, para. 131.

47 Ibidem, para. 164.
} 